\title{
Phase Diagram Evaluations
}

\begin{abstract}
The Journal contains provisional evaluated phase diagrams (together with associated data) of systems that are of principal interest to those in metallurgy and metals-related fields, including metal-metal, metal-metalloid, and metal-gas systems; the various forms of presentation can include pressure-temperature, metastable, and multicomponent diagrams.

All evaluations are contributed to the Journal by Category Editors, Contributing Editors, and their co-investigators. To enhance the value of the list of references accompanying each evaluation, the editors are providing some additional specific information in parentheses following each reference. These annotations will include indication of: (a) key papers, by an asterisk placed in front of the reference designation (e.g., *1983Abc); (b) nature of the data available (i.e., Equilibrium Diagram, Metastable Phases, Crystal Structure, Thermodynamics, and Pressure); (c) document classification (i.e., Experimental, Theory, Review, or Compilation); and (d) presence of an accepted phase diagram, or portion of one, by a number sign (\#) at the end of the annotation. References frequently cited in evaluations that follow are cited by author name rather than by number; these general references are listed below.
\end{abstract}

\section{General References}

[Elliott]: R.P. Elliott, Constitution of Binary Alloys, First Supplement, originally published by McGraw-Hill, reprinted and available from Genium Publishing, Schenectady, NY, 1965

[Hansen]: M. Hansen and K. Anderko, Constitution of Binary Alloys, originally published by McGraw-Hill, reprinted and available from Genium Publishing, Schenectady, NY, 1958

[Hultgren,B]: R. Hultgren, P.D. Desai, D.T. Hawkins, M. Gleiser, and K.K. Kelley, Selected Values of the Thermodynamic Properties of Binary Alloys, American Society for Metals, Metals Park, OH, 1973

[Hultgren,E]: R. Hultgren, P.D. Desai, D.T. Hawkins, M. Gleiser, K.K. Kelley, and D.D. Wagman, Selected Values of the Thermodynamic Properties of the Elements, American Society for Metals, Metals Park, OH, 1973

[Kingl]: H.W. King, Crystal Structures of the Elements at $25^{\circ} \mathrm{C}$, Bull. Alloy Phase Diagrams, Vol 2 (No. 3), 1981, p 401-402

[King2]: H.W. King, TemperatureDependent Allotropic Structures of the Elements, Bull. Alloy Phase Diagrams,
Vol 3 (No. 2), 1982, p 275-276; Vol 3 (No. 3), 1982, p 308

[King3]: H.W. King, Pressure-Dependent Allotropic Structures of the Elements, Bull. Alloy Phase Diagrams, Vol 4 (No. 4), 1983, p 449-450

[Landoll]: Landolt-Bornstein Tables, New Series, Group II, Structure Data of Elements and Intermetallic Compounds, Vol 6, Springer-Verlag, New York, 1971

[Massalskil]: T.B. Massalski, J.L. Murray, L.H. Bennett, and H. Baker, Binary Alloy Phase Diagrams, Vol 1 and 2, American Society for Metals, Metals Park, OH, 1986

[Massalski2]: T.B. Massalski, P.R. Subramanian, H. Okamoto, and L. Kacprzak, Ed., Binary Alloy Phase Diagrams, 2nd ed., Vol 1, 2, and 3, ASM International, Materials Park, OH, 1990

[Melt]: Melting Points of the Elements, Bull. Alloy Phase Diagrams, Vol 7 (No. 6), 1986, p 601-602

[Metals]: Metals Handbook, Metallography, Structures and Phase Diagrams, Vol 8, 8th ed., American Society for Metals, Metals Park, OH, 1973
[Moffatt]: W.G. Moffatt, Handbook of Binary Phase Diagrams, Genium Publishing, Schenectady, NY, 1978 and Supplements

[Pearsonl]: W.B. Pearson, Handbook of Lattice Spacings and Structures of Metals and Alloys, Vol 1, Pergamon, New York, 1958

[Pearson2]: W.B. Pearson, Handbook of Lattice Spacings and Structures of Metals and Alloys, Vol 2, Pergamon, New York, 1967

[Pearson3]: P. Villars and L.D. Calvert, Pearson's Handbook of Crystallographic Data for Intermetallic Phases, Vol 1, 2, and 3, American Society for Metals, Metals Park, OH, 1985

[Pearson4]: P. Villars and L.D. Calvert, Pearson's Handbook of Crystallographic Data for Intermetallic Phases, 2nd ed., Vol 1, 2, 3, and 4, ASM International, Materials Park, OH, 1991

[Shunk]: F.A. Shunk, Constitution of Binary Alloys, Second Supplement, originally published by McGrawHill, reprinted and available from Genium Publishing, Schenectady, NY, 1969 